\title{
Neo-industrialization of the economy in diffusion conditions socio-economic environments
}

\author{
Tetyana Calinescu ${ }^{1}$, Ganna Likhonosova ${ }^{2, *}$, and Olena Zelenko ${ }^{3}$ \\ ${ }^{1}$ Professor, Doctor in Economics Science Finance Department, 61070 National Aerospace University \\ "Kharkiv Aviation Institute", Kharkiv, Ukraine \\ ${ }^{2}$ Associate Professor, Doctor in Economics Science Finance Department, 61070 National Aerospace \\ University "Kharkiv Aviation Institute", Kharkiv, Ukraine \\ ${ }^{3}$ Associate Professor, Doctor in Economics Science, International Economic and Tourism \\ Department, 93406 Volodymyr Dahl East Ukrainian National University, Severodonetsk, Ukraine
}

\begin{abstract}
Socio-economic achievements of Ukraine are currently characterized not only by positive but also by negative trends, such as the creation of political confrontations, provoking international conflicts and the emergence of military aggression. Therefore, there is a need to indicate the directions of development and competitiveness of the social and economic potential of Ukraine in the conditions of the established European integration tendencies. The authors discovered the patterns of emergence of the main risks of socio-economic development of the country, which threaten the free access to a large raw material base, which creates the possibility of reducing the stiffness of pressure on Ukrainian producers on the need to increase labour productivity and technological modernization. The authors conclude that integration aspirations in the world social and economic system in Ukraine should be complemented by facilitating cooperation within the country itself. The lack of national socio-economic development program, which basis on the formation of the platform for socio-economic potential, combined with the effect of synergy effects can lead to unpredictable destructive consequences. Therefore, further research of these processes will be connecting to the exposures of multi-disciplinary connections, to found same trends and to do its interpretation.
\end{abstract}

\section{Introduction}

While most of the world's leading countries have achieved the sixth technological development, Ukraine still cannot cross the fifth. The resistance to innovative development significantly impedes the development of the country's competitiveness on the world market. In spite of the improvement of the situation in comparison with 2017 (83 in comparison with 89), in 2018 the country could not cross the barrier and enter the top ten global ranking among 140 countries (Fig. 1). The highest negative impact on the place in

\footnotetext{
* Corresponding author: a.likhonosova@gmail.com
} 
the rating is made by the level of macroeconomic stability (131 place), the state of the financial system (117th place).

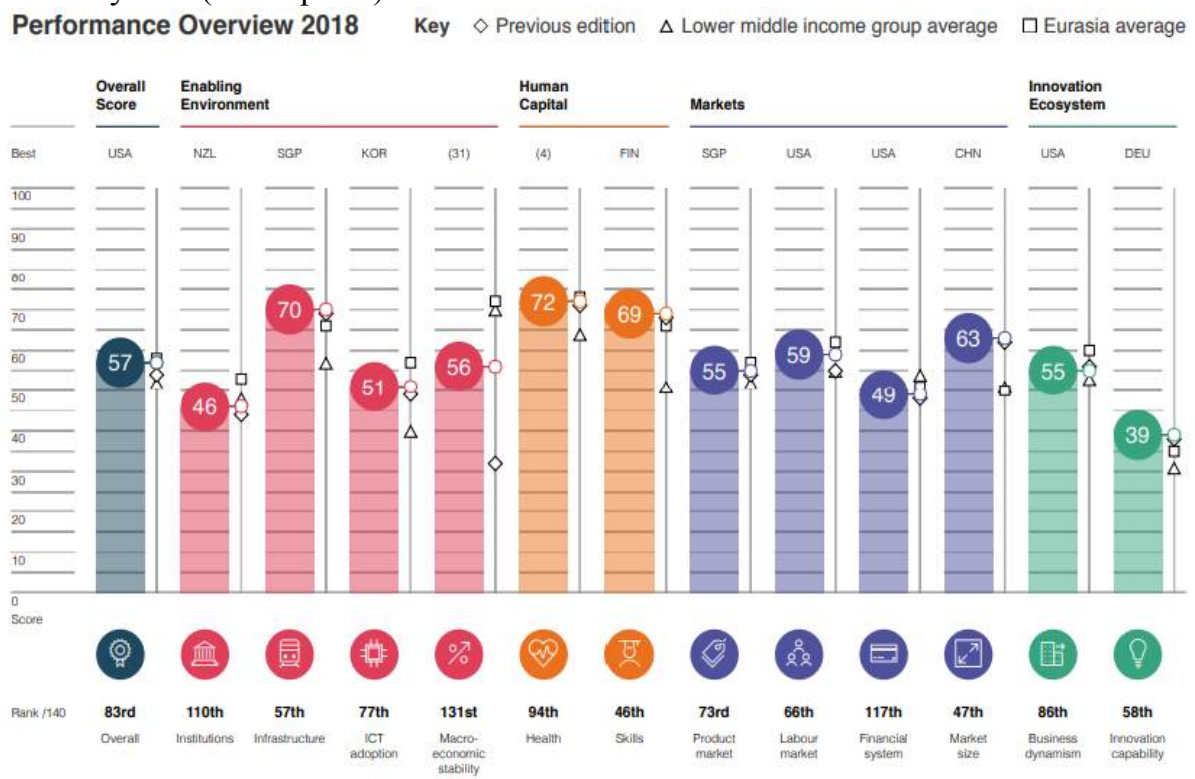

Fig. 1. Ukraine's place in the global competitiveness rating

Source: [1]

Indicators of the world ranking of competitiveness are also confirmed by negative tendencies of socio-economic development, therefore the question of finding ways to further effective development is more than ever relevant for Ukraine [1]. Neoindustrialization can be seen as a process with a certain purpose, methods, tools, technology and development strategies, sources of funding, and socio-economic implications that require a separate thorough study, in which a specified collective of authors attempts to develop regulators of reflection of national interaction in conditions of diffusion of socially -economic environments.

However, such socio-economic achievements are accompanied by negative consequences, such as the creation of political confrontations, provoking international conflicts and the emergence of military aggression. And these phenomena are accompanied by modern integration processes in Ukraine. Therefore, there is a need to indicate the directions of development of the socio-economic potential of Ukraine in the conditions of the established European integration tendencies and corresponding diffuses.

\section{Methodological analysis of recent research}

Problems of neo-industrialization became widely publicized both in developed countries of the world and in countries that only started this way. The most famous in this area is the publication of Peter March "The New Industrial Revolution: Consumers, Globalization, the End of Mass Production" [2], which was unveiled in 2012.

Among domestic scientists, supporters of neo-industrialization are D. Bodrova [3], V. Reshetylo [4] and others. Both domestic and foreign researchers emphasize the prospect of neo-industrialization and advancement of the services sector, which corresponds to the tertiary sector of the economy. According to many experts, special attention should be paid 
to the field of information services, which is sometimes separated into the quaternary sector of the economy.

In addition, the world has accumulated considerable experience and diversity of forms of international economic cooperation focused on integration tendencies. Questions of the relationship between economic integration and the dynamics of potential expansion are discussed in the context of the integration of financial markets and the growth of industrial specialization [5]. D. Brou and M. Ruth have built a model that shows that in cases where economic integration is accompanied by cooperation at the political level, it intensifies innovation activity, as firms in such conditions face less rigorous competition [6]. On this basis, the potential of socio-economic development, which will be based only on better access to resources, raw materials, commodity markets and financial capital, is negligible.

\section{Features of neo-industrialization process in Ukraine}

Neo-industrialization processes have begun to gain momentum within the last decade, and after the Fourth Industrial Revolution, they are actively implementing the system of economic relations in the level of developed countries and internationally.

Ukraine still cannot boast of the consistency of the above processes, according to the rating of the global index of innovations it occupies only $43^{\text {rd }}$ place. Institutions and infrastructure remain the weakest link in innovation development $\left(89^{\text {th }}\right.$ and $107^{\text {th }}$ in the country ranking, respectively) [7]. The level of knowledge intensity of the main macroeconomic indicator - GDP - has decreased by 1.7 times over the past 8 years, with participation of the state. Changes in the structure of the domestic industry in recent years indicate an increase in disproportions and an increase in the share of metallurgy and energy with a significant reduction in the share of processing industries.

\subsection{Integration trends as the basis of neo-industrialization of the economy}

Intensification of international cooperation can provide new opportunities for accelerating social and economic development at certain levels (Fig. 3).

Among the main positive trends in the integration processes in the field of socioeconomic potential formation [8], the country can be distinguished: ensuring the competitiveness of national industries as a result of their use of innovative behaviour and the development of new technologies and the accumulation of innovative knowledge and empirical skills by economically active subjects. The general market provides opportunities not only for acquisition of a greater spectrum of new production technologies and equipment, but also the training of a large number of organizational innovations. With the intensification of interaction its participants learn faster [9]. At the level of enterprises and the international exchange of knowledge-intensive resources and goods, the integration of markets has not yet become an incentive for breakthrough development. The actual reflection of this is the figures in Table 1. In 2017 the share of the research workers (researchers, technicians and auxiliary staff) in the total number of employment was $0.58 \%$, including researchers $-0.37 \%$ (Official website of the State Statistics Service of Ukraine). According to Eurostat, in 2015 the highest share of this share was in Finland (3.21\% and $2.35 \%)$, Austria (3.10\% and $1.92 \%)$ and Sweden $(2.97 \%$ and $2.33 \%)$; the lowest is in Romania $(0.53 \%$ and $0.33 \%)$, Cyprus $(0.83 \%$ and $0.61 \%)$, Poland $(1.0 \%$ and $075 \%)$ and Bulgaria (1.0\% and $0.65 \%)$ [10].

\subsection{Educational expectations from the behaviour of the population in the context of neo-industrialization}


One of the main directions of stimulation of new industrialization is the formation of an environment conducive to business development in the country. In a context of a shortage of investment resources in the real sector of the national economy, limited opportunities for public investment lending and the availability of socio-economic and political risks [11].

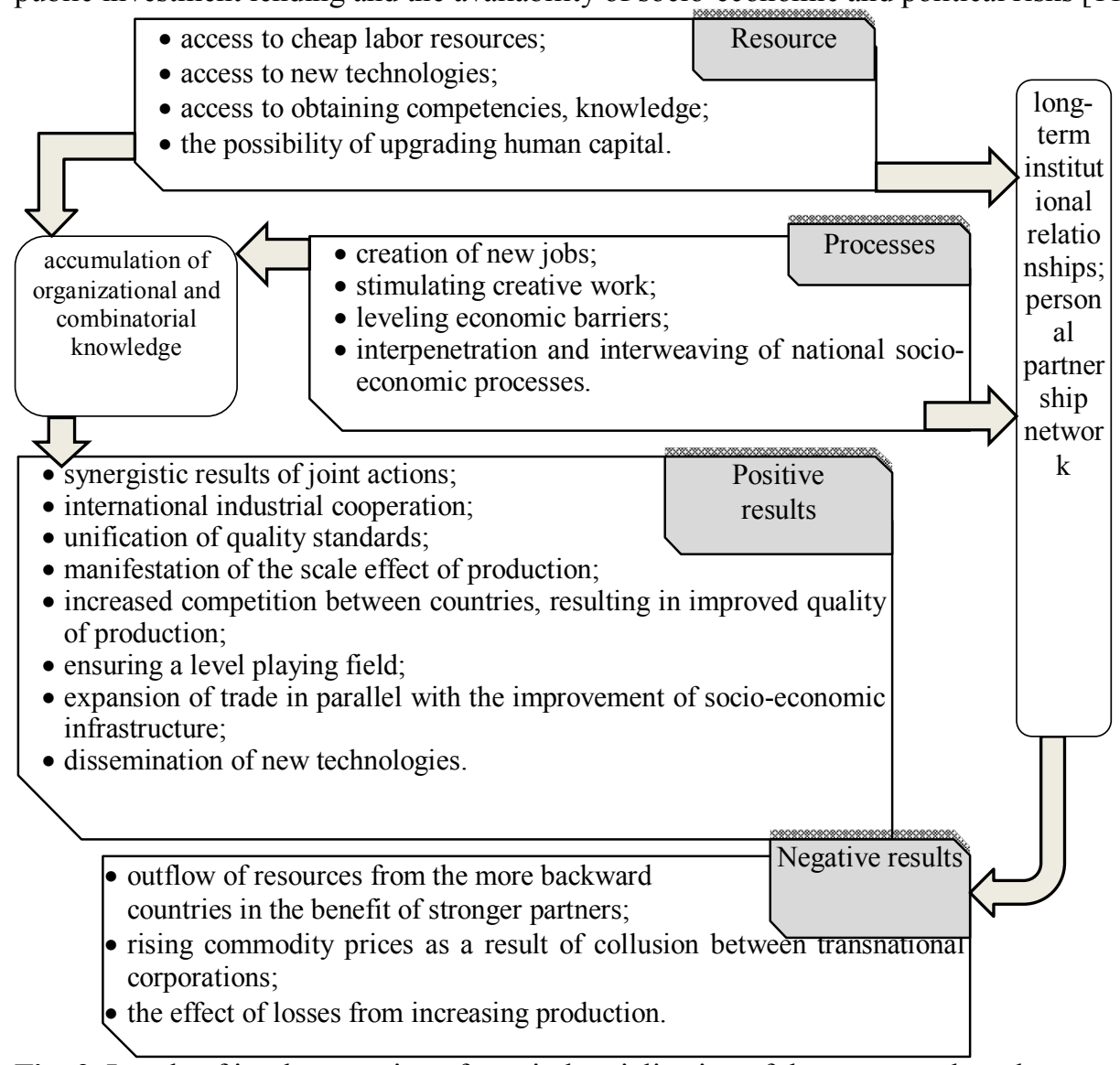

Fig. 2. Levels of implementation of neo-industrialization of the economy based on integration trends

Source: Developed by authors

At present, investments in industry, agriculture, transport and logistics, the development of hotel and restaurant business and public administration are the largest percentage of investments in the Ukrainian economy [12].

And if the percentage of investments in all positions gradually increases during 20072018 (the total investment in the economy of Ukraine increased by $35.7 \%$ ), then the investment in public administration is significantly reduced. In addition, during the period of 2007-2018, the share of investment in mining and processing industries, electricity generation, gas and the production of associated equipment for servicing it substantially grows in the structure of investments into industry [13].

At the same time, investments in the production of rubber, plastic and non-metallic products decreased. In total, investing in industry increased over the years by $38.8 \%$.

Further neo-industrial development of Ukraine is determined by the ability to find answers to a number of structural, technological and managerial challenges that have emerged as a result of global trends and transformations in the national economy during 
times of crisis. And this implies qualitative changes in the political and socio-economic spheres, which ultimately affects the results of general socio-economic development.

Table 1. The number of employees involved in the implementation of research and development by category (persons)

\begin{tabular}{|c|c|c|c|c|c|c|}
\hline \multirow{3}{*}{ Year } & \multirow{3}{*}{$\begin{array}{c}\text { Number of } \\
\text { employees } \\
\text { - total }\end{array}$} & \multicolumn{5}{|c|}{ Including } \\
\hline & & \multicolumn{2}{|c|}{ Persons that have a degree } & \multirow[b]{2}{*}{ researchers } & \multirow[b]{2}{*}{ technologist } & \multirow{2}{*}{$\begin{array}{c}\text { auxiliary } \\
\text { staff }\end{array}$} \\
\hline & & $\begin{array}{l}\text { doctor of } \\
\text { sciences }\end{array}$ & $\begin{array}{c}\text { doctor of } \\
\text { philosophy (Ph.D) }\end{array}$ & & & \\
\hline $2010^{1}$ & 182,484 & 11,974 & 46,685 & 133,744 & 20,113 & 28,627 \\
\hline $2011^{1}$ & 175,330 & 11,677 & 46,321 & 130,403 & 17,260 & 27,667 \\
\hline $2012^{1}$ & 164,340 & 11,172 & 42,050 & 122,106 & 15,509 & 26,725 \\
\hline $2013^{1}$ & 155,386 & 11,155 & 41,196 & 115,806 & 14,209 & 25,371 \\
\hline $2014^{1,3}$ & 136,123 & 9,983 & 37,082 & 101,440 & 12,299 & 22,384 \\
\hline $2015^{1,3}$ & 122,504 & 9,571 & 32,849 & 90,249 & 11,178 & 21,077 \\
\hline $2016^{2,3}$ & 97,912 & 7,091 & 20,208 & 63,694 & 10,000 & 24,218 \\
\hline $2017^{2,3}$ & 94,274 & 6,942 & 19,219 & 59,392 & 9,144 & 25,738 \\
\hline
\end{tabular}

${ }^{1}$ Data for 2010-2015 include permanent and temporary workers (contractors and persons working under civil-law contracts, including scientific and pedagogical workers).

${ }^{2}$ Data for 2016 are given without taking into account scientific and pedagogical workers who did not conduct research and development

${ }^{3}$ The data are given without taking into account the temporarily occupied territory of the Autonomous Republic of Crimea,

Sevastopol and parts of the zone of the anti-terrorist operation.

Source: Official site of the State Statistics Service of Ukraine

Undeniably, the structure of the socio-economic environment can interfere or promote the spread of neo-industrialization processes, which determines the obtaining of different effects and synergistic efficiency. The defining of this is the established norms, standards and rules of conduct of members of the social system, which then point to individual individuals whose behaviour or perception of the results of neo-industrialization is expected from them. Proceeding from this, can propose the following system of measures and directions for the formation of the synergistic effect of the country's socio-economic potential in the integration processes.

1) Restructuring of the institutional framework for socio-economic cooperation: development of an integrated strategy of social and economic cooperation at different levels. 2) Development of intellectual property rights protection system: introduction of educational programs for the study of patent experts with the study of international aspects of intellectual property rights management; development of special schemes for the protection of intellectual property rights and the provision of consulting services in area. 3) Development of domestic demand for innovation: to introduce mechanisms of support of industrial enterprises of all forms of ownership and of all sizes in the development of innovative technologies and equipment. 4) The intensification of trade in high-tech goods and technologies: to develop the competence of Ukrainian economic subjects in the marketing of knowledge-intensive goods and management of socio-economic systems; to stimulate alliances of enterprises to jointly bear the costs of patenting science-intensive products. 5) Targeting of attracted foreign investments: development of adequate schemes for resolving socio-economic conflicts; development of sectorial investment strategies, in which strategic socio-economic objectives should dominate financial goals. 6) Activation and stimulation of the mobility of young scientists: development of special programs for bilateral projects of young scientists' cooperation with their counterparts from other countries where Ukrainian scientists could conduct research in cooperation with foreign colleagues. 7) Implementation of schemes for the harmonization of education systems: institution based on the classical universities of centres for the preparation of the required 
specialties in cooperation with leading foreign universities within the framework of accredited programs; development of direct partnership links between universities of Ukraine. 8) Implementation of social dialogue at the regional and national levels: audit and updating of the existing regulatory and legislative framework for the formation of social dialogue with a view to involving a wide range of participants.

\section{Conclusions}

In the socio-economic environment, we should speak about the consequences of neoindustrialization and changes affecting the level of diffusion, which are not always measurable. Therefore, it can be argued that some effects can be measured by known methods and methods, but not all are subject to traditional measurement, and even do not yield positive results, and therefore can deepen the gaps, inequalities, imbalances of the entire socio-economic environment. Thus, the level of diffusion (access to information) of the socio-economic environment can contribute to the development of further priorities of neo-industrialization or to deepen the problem aspects, and then special measures should be taken to align the situation and its compliance with generally accepted standards or norms of the world's society.

\section{References}

1. K. Schwab. The Global Competitiveness Report. Geneva: World Economic Forum (2018).

2. P. Marsh. Levelling out: emerging markets and the New Industrial Revolution. Financial Times, 27 (2012).

3. D. Bodrova. Institutional factors of the neo-industrialization of the national economy. Intelligence XXI, 2 (2017).

4. V. Reshetilo. Neo-industrialization and its influence on the development of national and international economy. Scientific Bulletin of Uzhgorod National University. Series: International Economic Relations and the World Economy, 18 (2018).

5. A. Bommier, L. Bretschger, Le Grand. Existence of equilibria in exhaustible resource markets with economies of scale and inventories, Economic Theory, 63 (2017).

6. D. Brou, M. Ruta. Economic integration, political integration or both? Journal of the European Economic Association, 9(6) (2011).

7. S. Dutta, B. Lunvin, S. Wunsch-Vincent. Global innovation index 2018: Energizing the World with Innovation. Cornell INSEAD WIPO (2018).

8. Стан розвитку науки і техніки, результати наукової і науково-технічної діяльності за 2017 рік: аналітична довідка. Київ: Український інститут науково-технічної експертизи та інформації (2018).

9. T. Calinescu, G. Likhonosova, O. Zelenko. Estimation of conditions the realization of democratic mechanisms the transformation of society: tearing away and social dialog, Montenegrin Journal of Economics, 1(14) (2018).

10. A. Pobol. Economic potential of innovative development of countries in the integration processes of the CIS, EurAsEC and the CES, Eurasian Economic Integration, 1 (14) (2012).

11. Official site of the Statistical Service of the European Union (Eurostat). Retrieved June 8, 2019, available at: https://ec.europa.eu/eurostat/

12. T. Calinescu, G. Likhonosova, O. Zelenko. Mechanism of Transformation Socio-Economic Potential of Ukraine: Tearing Away and Social Dialogue. Proceeding of the 32nd International Business Information Management Association Conference (IBIMA), 15 - 16 November 2018, Seville Spain. Vision 2020: Sustainable Economic Development and Application of Innovation Management from Regional expansion to Global Growth. Seville Spain: IBIMA (2018).

13. L. Shavaliuk. The mirror of development. What the structure in the economy of Ukraine signals about. The Ukrainian week, 3(133) (2019). 